\title{
Pengaruh Pemberian Minyak Hati Ikan Hiu Botol (Centrophorus atromarginatus) Terhadap Kolesterol Total Darah Tikus Hiperkolesterolemia
}

\section{The Influence of Bottle Sharks Liver Oil (Centrophorus atromarginatus) on the Blood Total Cholesterol of hypercholesterolemic Rats}

\author{
Siti Fatimah ${ }^{1 *}$, Muhammad Radifar ${ }^{1}$, Tiara Madanti ${ }^{1}$ \\ ${ }^{1}$ Prodi D3 Analis Kesehatan STIKes Guna Bangsa Yogyakarta. \\ *Coresponding Author: siti_fatimah@gunabangsa.ac.id
}

\begin{abstract}
Abstrak
Kolesterol merupakan bahan semacam lilin dan seperti lemak yang terdapat di jaringan dan plasma. Penumpukan kolesterol akan mengakibatkan aterosklerosis. Endapan-endapan kolesterol yang mengeras dalam pembuluh darah tersebut sangat rapuh dan mudah pecah. Bekuan darah dan penyumbatan pembuluh darah dapat berakibat stroke atau serangan jantung.Telah dilakukan penelitian untuk mengetahui pengaruh pemberian minyak hati ikan hiu botol (Centrophorus atromarginatus) terhadap kadar kolesterol total darah tikus hiperkolesterolemia yang diberi pakan lemak tinggi.

Penelitian ini dilakukan secara eksperimental dengan menggunakan 25 ekor tikus putih jantan (Rattus Novergicus, L.), berumur 2-3 bulan dengan berat 150-200 g, yang dibagi dalam 5 kelompok perlakuan secara acak, yaitu kelompok K1 (Kontrol normal) diberi pakan standar, kelompok K2 (kontrol positif) diberi pakan lemak tinggi selama 7 hari, sedangkan kelompok P1, P2 dan P3 diberi minyak hati ikan hiu botol secara peroral dengan dosis 54mg/ $200 \mathrm{gBB} / \mathrm{hari}$, $108 \mathrm{mg} / 200 \mathrm{gBB} / \mathrm{hari}, 216 \mathrm{mg} / 200 \mathrm{~g}$ BB/hari. Setiap perlakuan terdiri dari 5 ekor tikus yang dilakukan 3 kali pemeriksaan kadar kolesterol total dengan metode CHOD-PAP.

Data yang diperoleh dari pemeriksaan dianalisis menggunakan ANOVA satu arah $\mathrm{p}<0,005$ dilanjutkan post hoct test. Hasil Penelitian kelompok P1, P2, dan P3 berbeda bermakna dengan $\mathrm{K} 1 \quad(\mathrm{p}=0,000)$. Kelompok $\mathrm{P} 1$, P2, dan $\mathrm{P} 3$ berbeda bermakna dengan $\mathrm{K} 2$ $(p=0,000)$. Minyak hati ikan hiu botol dengan dosis $54 \mathrm{mg} / 200 \mathrm{~g} \mathrm{BB} /$ hari, $108 \mathrm{mg} / 200 \mathrm{~g} \mathrm{BB} / \mathrm{hari}$, $216 \mathrm{mg} / 200 \mathrm{~g} \mathrm{BB} /$ hari masing-masing dapat menurunkan kadar kolesterol sebesar $23 \%$ atau $43,67 \mathrm{mg} / \mathrm{dl}$, $30 \%$ atau $55,72 \mathrm{mg} / \mathrm{dl}$, dan $38 \%$ atau $70,94 \mathrm{mg} / \mathrm{dl}$.
\end{abstract}

Kata kunci : hiperkolesterolemia, kolesteol total, minyak hati ikan hiu botol

\section{Abstract}

Cholesterol is a wax-like ingredient and is like fat found in tissues and plasma. Cholesterol buildup will cause atherosclerosis. Cholesterol deposits that harden in these blood vessels are very fragile and easily broken. Blood clots and blockage of blood vessels can result in strokes or heart attacks. Research has been conducted to determine the effect of bottle shark liver oil (Centrophorus atromarginatus) on total cholesterol levels of hypercholesterolemic bloods rats with high fat feed.

This research was carried out experimentally using 25 male white rats (Rattus Novergicus, L.), aged 2-3 months with a weight of 150-200 g, which were divided into 5 treatment groups randomly, ie group K1 (normal control) fed standard, K2 group (positive control) was given high fat feed for 7 days, while group P1, P2, and P3 were given bottle shark liver oil orally with a dose of $54 \mathrm{mg} / 200 \mathrm{gBB} /$ day, $108 \mathrm{mg} / 200 \mathrm{gBB} /$ day, $216 \mathrm{mg} / 200 \mathrm{~g} \mathrm{BB}$ /day. Each treatment consisted of 5 rats which were examined 3 times the total cholesterol level by the CHOD-PAP method.

Data obtained from examinations were analyzed using one-way ANOVA $p<0.005$ followed by post hoct test. The results of the P1, P2, and P3 groups were significantly different from $K 1(p=0,000)$. Groups $P 1, P 2$, and $P 3$ were significantly different from $K 2(p=0,000)$. Bottle shark liver oil with a dose of $54 \mathrm{mg} / 200 \mathrm{~g}$ BB / day, 108mg / 200g BB / day, 216mg / $200 \mathrm{~g}$ 
BB / day each can reduce cholesterol levels by $23 \%$ or $43.67 \mathrm{mg} / \mathrm{dl}, 30 \%$ or $55,72 \mathrm{mg} / \mathrm{dl}$, and $38 \%$ or $70.94 \mathrm{mg} /$

Key word : bottle shark liver oil, hypercholesterolemia, total cholesterol

\section{PENDAHULUAN}

Menurut pusat data dan informasi kementrian kesehatan $\mathrm{Rl}$ tahun 2014, setiap tahunnya lebih dari 36 juta orang meninggal karena penyakit tidak menular. Secara global penyakit tidak menular yang menyebabkan kematian nomor satu setiap tahunnya yaitu penyakit yang disebabkan oleh gangguan fungsi jantung dan pembuluh darah, seperti penyakit jantung koroner (PJK), penyakit gagal jantung, dan stroke. Berdasarkan diagnosis dokter prevalensi PJK di Indonesia tahun 2013 sebesar $0,5 \%$ atau sekitar 883.447 orang, sedangkan diagnosis dokter prevalensi gejala sebesar $1,5 \%$ atau sekitar 2.650 .340 orang, dan prevalensi stroke di Indonesia berdasarkan diagnosis dokter sebesar 7,0\% sekitar 1.236.825 orang (Kementrian Kesehatan RI, 2014).

PJK adalah gangguan fungsi pembuluh darah yang mengalami sumbatan, yang menyuplai makanan dan oksigen untuk otot jantung (Kurniadi dan Nurrahmani, 2014). Pemasukan kolesterol ke dalam tubuh yang masih seimbang dengan kebutuhan tubuh maka tubuh akan tetap sehat dan tidak terganggu mekanisme kerjanya (Nilawati, dkk., 2008).

Hiperkolesterolemia adalah peningkatan kadar kolesterol di dalam darah. Kadar kolesterol darah yang tinggi merupakan masalah yang serius karena merupakan salah satu faktor risiko yang paling utama untuk terjadinya PJK selain faktor lainnya, seperti tekanan darah tinggi dan merokok. Kadar kolesterol yang tinggi dapat mengganggu kesehatan, bahkan mengancam kehidupan manusia (Anies, 2015).

Aterosklerosis ditandai dengan penebalan dinding pembuluh darah arteri sehingga terjadi penyempitan lumen pembuluh darah, merangsang pembentukan pembekuan darah yang menghambat aliran darah ke jantung, otak dan jaringan paru-paru (Linder, 2010). Peningkatan kadar kolesterol di dalam darah (hiperkolesterolemia) merupakan salah satu faktor resiko yang paling utama terjadinya PJK (Anies, 2015).

Ikan hiu botol yang terdapat di perairan laut Indonesia memiliki panjang tubuh 1,5 meter dengan berat 50 kilogram dan kandungan minyak di dalam hatinya mencapai $85 \%$. Hati ikan hiu botol (Centrophorus atromarginatus) memiliki kandungan minyak hampir $80 \%$ dari bobot hati ikan hiu botol, squalen, asam lemak omega 3 , omega 6 , omega 9 yang merupakan asam lemak yang esensial dalam tubuh (Insani, dkk., 2017). Squalen yang terdapat pada ikan mampu untuk menurunkan kadar kolesterol dalam darah, dengan meningkatkan kapasitas penyaringan hati. Mekanisme ini berasal dari kemampuannya untuk mengatur HMG Co-A reduktase, yang pada gilirannya meningkatkan kemampuan hati untuk menyaring 
kolesterol jahat (Kurniawan, dkk., 2009).

\section{METODE PENELITIAN Alat dan Bahan}

Alat yang diperlukan dalam penelitian ini adalah kandang hewan uji, timbangan analitik, spektrofotometer UV-Vis, kuvet, centrifuge, mikropipet $100 \mu \mathrm{l}$ dan $1.000 \mu \mathrm{l}$, tip warna kuning dan biru, tabung mikropipet, kapas alkohol $70 \%$, kapas kering, rak tabung reaksi, hand gloves, jas lab, masker, gelas kimia, kulkas. Bahan yang digunakan dalam penelitian ini adalah reagen cholesterol fs, dan reagen standar kolesterol, minyak hati ikan hiu botol.

\section{Persiapan Hewan percobaan}

Tikus putih sebanyak 25 ekor diadaptasi selama 2 hari menggunakan kandang individu. Tikus diberi pakan standar dan akuades yang cukup. Pada hari terakhir adaptasi dilakukan pengukuran kadar kolesterol total menggunakan metode CHOD-PAP menggunakan spektrofotometer.

\section{Pengujian Efek Minyak Ikan Hiu Botol}

Masing-masing kelompok tediri dari 5 ekor tikus putih wistar. Berat badan tikus putih ditimbang kemudian kadar kolesterol total darah tikus putih diukur pada hari ke-3. Tikus putih diberi pakan tinggi lemak sapi $2 \mathrm{ml} / \mathrm{ekor} /$ hari selama 7 hari dengan cara sonde lambung. Berat badan tikus ditimbang dan diukur kadar kolesterol total (pre-test). Pengujian kadar kolesterol total pada tikus putih yang dibagi menjadi 2 kelompok kontrol (kontrol normal dan kontrol positif) dan 3 kelompok perlakuan diberi minyak hati ikan hiu botol yang terdiri dari 3 dosis selama 14 hari.

1) Kelompok 1 (K1) sebagai kontrol normal

2) Kelompok 2 (K2) sebagai kontrol kolesterol total tinggi

3) Kelompok 3 (P1) sebagai perlakuan 1 (54 mg/200gBB/hari minyak hati ikan hiu botol)

4) Kelompok $4 \quad(P 2)$ sebagai perlakuan 2 (108 mg/200gBB/hari minyak hati ikan hiu botol)

5) Kelompok $5 \quad$ (P3) sebagai perlakuan $3(216 \mathrm{mg} / 200 \mathrm{gBB} / \mathrm{hari}$ minyak hati ikan hiu botol).

\section{Persiapan Spesimen}

Sampel darah diambil pada bagian vena tikus putih dengan meggunakan tabung mikrokapiler malalui sinus orbitalis. Darah yang keluar dari tabung mikrokapiler langsung ditampung pada cup serum sebanyak kira-kira 0,5-1 mL. Darah didiamkan selama 30 menit pada suhu kamar agar darah membeku. Darah yang telah membeku disentrifus selama 15-20 menit dengan kecepatan 4000 rpm. Serum yang telah terbentuk lalu dipindahkan ke dalam cup serum bersih dan diberi label kemudian serum siap untuk diperiksa.

\section{Persiapan Alat Spektrofotometer UV-Vis dan Pemeriksaan Kadar Kolesterol Total}

Alat spektrofotometer siap dioperasikan untuk pemeriksaan kadar kolesterol total menggunakan metode CHODPAP.

Reagen dicampur, kemudian diinkubasi selama 20 menit $20-250 \mathrm{C}$ atau 10 menit pada $37^{\circ} \mathrm{C}$. Absorbansi sampel dan standar dibaca terhadap blanko 
pada panjang gelombang $546 \mathrm{~nm}$. Pembacaan absorbansi tidak lebih dari 60 menit.

\section{Tabel 1. Prosedur Pemeriksaan Kadar Kolesterol Total Darah Metode CHOD-PAP}

\begin{tabular}{llll} 
& $\begin{array}{l}\text { Blanko } \\
(\mu \mathrm{l})\end{array}$ & $\begin{array}{l}\text { Standar } \\
(\mu \mathrm{l})\end{array}$ & $\begin{array}{l}\text { smpel } \\
(\mu \mathrm{l})\end{array}$ \\
\hline Serum & - & - & 10 \\
Standar & - & 10 & - \\
Reagen & 1.000 & 1.000 & 1.000
\end{tabular}

\section{Perhitungan kadar kolesterol total dengan metode CHOD-PAP}

Kadar kolesterol total $=\frac{A \text { sampel }}{A \text { standar }} \times$ konsentrasi standar $(200 \mathrm{mg} / \mathrm{dl})$

\section{HASIL DAN PEMBAHASAN}

Penelitian kadar kolesterol total pada 25 ekor tikus putih wistar yang dibagi menjadi 5 kelompok, masingmasing kelompok terdapat 5 ekor tikus. Hewan uji yang digunakan dalam penelitian ini adalah tikus putih (Rattus novergicus) jantan, tikus putih yang digunakan dalam penelitian ini berumur 3 bulan (umur tikus dewasa). K1 sebagai kelompok kontrol normal, K2 sebagai kelompok positif, dan kelompok P1, P2, dan P3 sebagai kelompok perlakuan minyak hati ikan hiu botol. Kelompok kontrol normal diadaptasi selama 2 hari dan diberi pakan standar dan kelompok K2, P1, P2, dan P3 diberi pakan tinggi lemak.

Pemeriksaan kadar kolesterol total pre-test (setelah diinduksi lemak sapi selama 7 hari) untuk mengetahui pemberian lemak sapi pada kelompok $\mathrm{K} 2$, P1, P2, dan P3 dapat meningkatkan kadar kolesterol total tikus putih sebanyak $70 \%$ atau 2 kali lipat. Pemeriksaan kadar kolesterol total post-test (setelah diberi minyak hati ikan hiu botol selama 14 hari) untuk mengetahui penurunan kadar kolesterol total pada tikus putih setelah diberi minyak hati ikan hiu botol dari berbagai dosis pada masing-masing kelompok perlakuan (P1, P2, dan P3). Kadar kolesterol total pada kelompok K1 tidak mengalami peningkatan atau penurunan karena kelompok tersebut berfungsi sebagai kelompok kontrol kadar kolesterol total normal sehingga tidak diinduksi lemak sapi dan minyak

hati ikan hiu botol.

Metode pemeriksaan kadar kolesterol total yang digunakan dalam penelitian ini adalah metode Cholesterol Oxidase Peroxidasae Aminoantipyrine Phenol (CHOD-PAP) secara enzimatis, dimana kolesterol oksidase akan menghasilkan peroksida dan bereaksi dengan 4-amino antipirin membentuk kuinoneimine yang berwarna merah muda. Metode ini paling banyak digunakan karena hasilnya lebih teliti, tetapi reagen harus disimpan dengan baik karena enzim mudah rusak (Panil, 2008 dalam Purbayanti 2015).

Tikus putih dipuasakan selama 8-12 jam sebelum dilakukan pemeriksaan kadar kolesterol total, hal ini disebabkan karena kandungan gizi dalam makanan dan minuman yang dikonsumsi oleh tikus putih akan diserap ke dalam aliran darah dan dapat memberikan dampak langsung 
pada kadar lemak. Tikus putih dipuasakan bertujuan untuk mengurangi variabilitas substansi tersebut dan variabilitas lainnya dalam darah. Hal ini untuk memastikan agar pemeriksaan tidak dipengaruhi oleh makanan terakhir yang dikonsumsi (Anna, 2014).

Hasil yang didapat dari penelitian ini berupa kadar kolesterol total pada tikus putih hiperkolesterolemia sebelum dan setelah pemberian minyak hati ikan hiu botol. Sebelum dianalisis statistik menggunakan Uji Statistik Paired $T$ Test terlebih dahulu dilakukan normalitas. Uji normalitas dilakukan dengan menggunakan Shapiro-Wilk. Hasil uji normalitas didapatkan semua data terdistribusi normal dimana ada nilai $p>0,05$. Berdasarkan hasil uji normalitas maka untuk analisis data variabel dalam penelitian ini dianalisis menggunakan paired $t$ test yang terdapat pada tabel 2.

Tabel 2. Deskripsi kolesterol total Sebelum dan Sesudah Pemberian minyak hati ikan hiu botol dengan paired t test

\begin{tabular}{ccccc}
\hline Kelompok & $\begin{array}{c}\text { Pre test } \\
\text { mean } \pm \text { SD }\end{array}$ & $\begin{array}{c}\text { Post test } \\
\text { mean } \pm \text { SD }\end{array}$ & $\begin{array}{c}\text { Delta } \\
\text { Perubahan }\end{array}$ & $\boldsymbol{p}$ \\
\hline K1 & $90,41 \pm 2.42$ & $90,24 \pm 2,48$ & 0.17 & 0,019 \\
K2 & $190,68 \pm 3,92$ & $192,41 \pm 3,95$ & 1.73 & 0,002 \\
P1 & $188,36 \pm 3,18$ & $144,68 \pm 2,80$ & 43.68 & 0,000 \\
P2 & $187,40 \pm 3,01$ & $131,68 \pm 4,40$ & 55.72 & 0,000 \\
P3 & $186,85 \pm 2,88$ & $115,91 \pm 2,63$ & 70.94 & 0,020 \\
\hline
\end{tabular}

Tabel 2 menyatakan bahwa rerata kadar kolesterol total sebelum pemberian minyak hati ikan hiu botol P1 (dosis 54mg/200g BB/hari), P2 (108mg/200g BB/hari), P3(dosis $216 \mathrm{mg} / 200 \mathrm{~g} \quad \mathrm{BB} / \mathrm{hari})$ berturut-turut adalah $188,36 \mathrm{mg} / \mathrm{dl}, 187,40 \mathrm{mg} / \mathrm{dl}$, $186,85 \mathrm{mg} / \mathrm{dl}$ dan sesudah pemberian minyak hati ikan hiu botol ialah berturutturut adalah 144,68 mg/dl, 131,68mg/dl, dan $115,91 \mathrm{mg} / \mathrm{dl}$. Rerata kolesterol total sesudah pemberian minyak hati ikan hiu botol lebih rendah dibandingkan sebelum pemberian. Hasil uji statistik paired $t$ test menyatakan bahwa ada beda rerata kadar kolesterol total antara sebelum dan sesudah pemberian minyak hati ikan hiu botol pada kelompok P1, P2 dan P3 $(P<0.05)$
Hasil analisis data menggunakan ANOVA satu arah $\mathrm{p}<0,005$, dilanjutkan post hoct test pada kelompok $\mathrm{P} 1, \mathrm{P} 2$, dan $\mathrm{P} 3$ berbeda bermakna dengan $\mathrm{K} 1$ $(p=0,000)$. Kelompok P1, P2, dan P3 berbeda bermakna dengan $\mathrm{K} 2$ $(p=0,000)$. Minyak hati ikan hiu botol dengan dosis $54 \mathrm{mg} / 200 \mathrm{~g} \mathrm{BB} / \mathrm{hari}$, $108 \mathrm{mg} / 200 \mathrm{~g} \quad \mathrm{BB} / \mathrm{hari}, \quad 216 \mathrm{mg} / 200 \mathrm{~g}$ $\mathrm{BB} /$ hari masing-masing dapat menurunkan kadar kolesterol sebesar $23 \%$ atau $43,67 \mathrm{mg} / \mathrm{dl}, 30 \%$ atau $55,72 \mathrm{mg} / \mathrm{dl}$, dan $38 \%$ atau 70,94 $\mathrm{mg} / \mathrm{dl}$. Hal tersebut menunjukkan semakin tinggi dosis yang diberikan maka persentase penurunan kadar kolesterol total semakin besar. Penurunan kadar kolesterol total terbesar terjadi pada kelompok 
perlakuan dengan dosis 216 $\mathrm{mg} / 200 \mathrm{gBB} /$ hari yaitu $38 \%$.

Hasil penelitian ini menunjukkan bahwa minyak hati ikan hiu botol memiliki efek hipokolesterolemia walaupun diberikan makanan lemak tinggi. Squalene yang terdapat pada ikan hiu botol mampu untuk menurunkan kadar kolesterol dalam darah, dengan meningkatkan kapasitas penyaringan hati. Mekanisme ini berasal dari kemampuannya untuk mengatur HMG Co-A reduktase, yang pada gilirannya meningkatkan kemampuan hati untuk menyaring kolesterol jahat. Minyak hati ikan hiu botol mengandung $90 \%$ squalen, vitamin $A$, dan omega yang sangat berguna untuk tubuh manusia sebagai suplemen penyakit jantung, tukak lambung, menambah stamina, dan kecerdasan otak (Kurniawan, dkk., 2009).

Minyak ikan hiu merupakan komponen lemak yang terkandung dalam jaringan tubuh ikan salah satunya yaitu hati ikan yang telah diekstraksi dalam bentuk minyak. Minyak ikan mengandung Squalen sebesar 12,49\%, asam lemak jenuh (SFA, Saturated Fatty Acid) sebesar $17,30 \%$, asam lemak tidak jenuh banyak ikatan rangkap (PUFA, Polyun Saturated Fatty Acid) sebesar 9,30\%, dan asam lemak tidak jenuh dengan satu ikatan rangkap (MUFA, Monoun Saturated Fatty Acid) sebesar 35,77\% (Insani, dkk., 2017).

Asam lemak tidak jenuh diklasifikasi-kan menjadi dua yaitu asam lemak tidak jenuh tungal (MUFA) yang terdiri dari $\omega-9$ (asam oleat dan asam palmitoleat), asam lemak tidak jenuh ganda (PUFA) yang terdiri dari $\omega$ 3 (asam linoleat dan asam linolenat) dan $\omega-6$ (asam arakhidonat. Asam lemak tidak jenuh ganda bermanfaat untuk menurunkan kadar kolesterol darah melalui penurunan sintesis lipoprotein dan meningkatkan katabolisme lipoprotein (Zimmerman, 2001 dalam Purnomo, 2014).

\section{KESIMPULAN}

Pemberian minyak hati ikan hiu botol $\quad 54 \mathrm{mg} / 200 \mathrm{gBB} /$ hari, $108 \mathrm{mg} / 200 \mathrm{gBB} /$ hari secara bermakna dapat menurunkan kadar kolesterol total pada tikus hiperkolesterolemia.

\section{UCAPAN TERIMA KASIH}

Peneliti mengucapkan terima kasih kepada RISTEK DIKTI atas dana yang telah diberikan untuk penelitian ini

\section{DAFTAR PUSTAKA}

Anna LK. 2014. Mengapa Perlu Puasa Sebelum Cek Kesehatan?. Diunduh dari websitehttp://lifestyle.kompas.co m/read/2014/05/07/1012387/Men gapa.Perlu.Puasa.Sebelum.Perik sa.Kesehatan. diakses pada tanggal 19 Juli 2018. Yogyakarta.

Anies. 2015. Kolesterol dan Penyakit Jantung Koroner: Solusi Pencegahan dari Aspek Kesehatan Masyarakat. Ar-Ruzz Media, Yogyakarta: 18, 31, 32, 35, 55, 56.

Insani SA, Suseno SH, Jacoeb AM. 2017. Karakteristik Squalene Minyak Hati Ikan Hiu Cucut Hasil Produksi Industri Rumah Tangga, Pelabuhan Ratu. Jurnal Institute Pertanian Bogor vol 20 (3) : 494504 
Kementrian Kesehatan Republik Indonesia, 2014, Situasi Kesehatan Jantung. Pusat Data danInformasi, Jakarta Selatan: 2.

Kurniawan, W., Nurfauzi, Y., dan Khalimi, 2009. Meningkatkan Perolehan Kadar Vitamin A dan Squalene pada Home Industri Pengolahan Minyak Hati Ikan Hiu di Masyarakat Nelayan Cilacap. Laporan Akhir Program IbM. STIKES Al-Irsyad Al-Islamiyyah Cilacap.

Nilawati S., Krisnatuti D., Mahendra.,Djing OG. 2008. Care Yourself Kolesterol. Penebar Plus, Jakarta:9.

Susilani AT dan Wibowo TA. 2015. Dasar-Dasar Metodologi Penelitian untuk Mahasiswa Kesehatan. Graha Cendikia, Yogyakarta: 102.

Purbayanti D., 2015. Pengaruh Waktu Penimpanan Serum Untuk Pemerik-saan Kolesterol Total. Jurnal Surya Medika. Vol. 1. 1:12

Purnomo S. 2014. Pengaruh Suplementasi Omega 3 Terhadap Profi Lipit Pada Pasien Diabetes Melitus Tipe 2 Obesitas di RSUD DR. Moewardi Surakarta. [Tesis] Program Studi IImu Gizi Program Pasca Sarjana Universitas Sebelas Maret. Surakarta. 